\title{
Plasma Lipid Profile in Obese Children and in Children with Hereditary Predisposition to Coronary Heart Disease
}

\author{
F. Ayşenur Pạ̧, M.D., M. Ramazan Yigitoglu, M.D.,
}

A. Gazi Kalayci, M.D., Bahattin Adam, M.D.,

Sebahattin Atesal, M.D., and Muzaffer Kürkcüoglu, M.D.

\begin{abstract}
Summary
This study examined risk factors for coronary disease and plasma triglycerides, total cholesterol, HDL, LDL cholesterol (C), Apo A-1, and Apo B lipoprotein levels in obese children $(n=107)$ aged 9-12 years old and in children $(\mathrm{n}=64)$ hereditarily predisposed to coronary heart disease (CHD). In the latter group, children's fathers had a history of MI before 50 years of age.

A control group of 30 children was also studied, and the plasma lipid profile was investigated in 35 fathers with premature myocardial infarction. Seventy-five percent of the obese children and $60 \%$ of the children hereditarily predisposed to CHD had three or more coronary artery disease risk factors. Plasma HDL-G $(p<0.001)$, LDL-G $(p<0.001-p<$ 0.05 , respectively), Apo A-1 ( $<<0.001)$, and Apo B $(\mathrm{p}<0.001)$ levels were different in both groups compared with controls.
\end{abstract}

\section{Key Words:}

Plasma triglyceride Cholesterol HDL and LDL cholesterol Apo A-1 and Apo B lipoproteins Coronary heart disease

\begin{abstract}
A UTOPSIES of young servicemen killed in the Korean and Vietnam conflicts revealed coronary artery atherosclerotic lesions.1,2) This discovery led both epidemiologists and clinicians to question whether atherosclerosis begins in childhood. If so, they reasoned it might be possible to identify high-risk individuals for intensive therapy. ${ }^{3)}$ In the Bogaluss heart study, black boys had higher Apo A-1 levels than white boys. ${ }^{4)}$ After the first year of life, serum cholesterol $(\mathrm{Ch})$ and lipoprotein levels approximatcd those of adults. ${ }^{5)}$ Recently, Stary $\left.{ }^{6}\right)$ confirmed that early coronary artery lesions can be seen at autopsy in at least $17 \%$ of infants and children under
\end{abstract}

From the Departments of Pediatrics, Biochemistry, and Cardiology, Atatïrk University, Research Hospital, Erzurum, Turkey.

Mailing address: F. Ayșenur Paç, M.D., Hülya Sok 14/13 G.O. Pașa, Ankara, Turkey.

Received for publication May 28, 1991.

Accepted February 3, 1992. 
5 years of age.

It has been demonstrated that dyslipoproteinemias with elevated levels of cholesterol ( $\mathrm{Ch}$ ) and Apo B containing low density lipoproteins (LDL-C) and low levels of $\mathrm{Ch}$ and Apo A-1 containing particles of high density lipoproteins (HDL-C), and family history of coronary heart disease (CHD) are CHD risk factors among adults." Some of the other risk factors are obesity, hypertension, high levels of triglycerides and low physical work capacity. ${ }^{8}$ In the present study, plasma lipid profiles and risk factors were investigated in obese children and in children with a hereditary predisposition to CHD.

\section{Materials and Methods}

Two groups of children were studied for determination of risk factors. The first group comprised 107 obese school children of both sexes in the age range 9-12 from a city in the east of Turkey called Erzurum. The other group consisted of 64 children whose fathers had premature coronary infarction (PCHD) before the age of 50. All the children had similar socioeconomic levels and dietary habits. Thirty control children were chosen without obesity and without a parental history of PCHD. Thirty-five fathers with PCHD were included in the study.

Obesity, hypertension, family history of CHD, plasma triglycerides, total (T) cholesterol, LDL-C, HDL-C, Apoprotein A-1, and B levels were investigated as risk factors. The criteria for obesity were body weight $20 \%$ higher than the ideal and triceps skinfold being greater than the 75 percentile with reference to age and sex. Blood pressures were taken after children had been resting in a supine position for $20 \mathrm{~min}$. A systolic blood pressure above $130 \mathrm{mmHg}$ and a diastolic blood pressure above $86 \mathrm{mmHg}$ were accepted as hypertension (above normal) for this age group.*

Venous blood samples were taken (after overnight fasting) into vacutainer tubes containing $1.0 \mathrm{~g} / 1$ disodium EDTA. Plasma was obtained by low speed centrifugation for $30 \mathrm{~min}$ at $4^{\circ} \mathrm{C}$. The plasma levels of cholesterol and triglycerides were measured on a Hitachi 705 Auto Analyzer, along with the HDL-C content after preliminary elimination of very low density LP and LDL from plasma with heparin manganese precipitation. The LDL-C level was calculated according to the formula of Friedwald et al. ${ }^{9)}$ Plasma concentrations of Apo A-1 and B were measured with immunoturbidimetric analysis, SPQ ${ }^{\mathrm{TM}}$ test system (Hitachi 4020 Fotometer-Atab).

* From Task Force on Blood Pressure Control in Children-National Heart, Iunng and Blood Institute: Report of the Second Task Force on Blood Pressure Control in Children-1987. 
Statistical analysis of the results was conducted using Student's t-test (Table I).

\section{Results}

Fifty-two percent of the obese students showed triglyceride values greater than $100 \mathrm{mg} / \mathrm{dl}$ and $13 \%$ had a triglyceride value greater than $200 \mathrm{mg} / \mathrm{dl}$. By contrast, the $22 \%$ of the children who had a family history of PCHD also had a triglyceride value greater than $200 \mathrm{mg} / \mathrm{dl}$ and $63 \%$ had a value higher than $100 \mathrm{mg} / \mathrm{dl}$. In this second group, $11 \%$ of both fathers and children displayed triglyceride values greater than $200 \mathrm{mg} / \mathrm{dl}$.

Total cholesterol value higher than $200 \mathrm{mg} / \mathrm{dl}$ was found in $43 \%$ of the obese children, $51 \%$ of the fathers with PCHD, and $18 \%$ of their children. Fifteen $\%$ of the obese children had LDL-C higher than $150 \mathrm{mg}$, as did $15 \%$ of the fathers with PCHD, although none of their children did.

Apo B levels higher than $85 \mathrm{mg} / \mathrm{dl}$ were found in $29 \%$ in the obese children, $22 \%$ in the fathers with PGHD, but in none of their children.

Blood pressures were above normal in $24 \%$ of the obese children (17 of them had abnormal lipid profiles), and $15 \%$ of children with a family history of PCHD.

Plasma lipid profile of all groups are shown in Table I. Risk factors are shown in Fig. 1. In the obese group $75 \%$ had three or more risk factors. In the other child group $60 \%$ had three or more risk factors.

As shown in Table I, plasma HDL-C, LDL-C, Apo A-1, and Apo B values were significantly different from control values in the obese children and children with a family history of PCHD.

Table I. Lipid Profile of the Groups (mean \pm standard deviations)

\begin{tabular}{l|r|r|r|r|r|r|r}
\hline \multirow{2}{*}{ Parameters } & \multicolumn{7}{|c|}{ Groups } \\
\cline { 2 - 8 } & $\begin{array}{r}\text { I } \\
42 \mathrm{~F} / 65 \mathrm{M}\end{array}$ & $\mathrm{p}$ & $\begin{array}{c}\text { II } \\
14 \mathrm{~F} / 16 \mathrm{M}\end{array}$ & $\mathrm{p}$ & $\begin{array}{c}\text { III } \\
28 \mathrm{~F} / 36 \mathrm{M}\end{array}$ & $\mathrm{p}$ & $\begin{array}{c}\text { IV } \\
35 \mathrm{M}\end{array}$ \\
\hline Triglyceride $(\mathrm{mg} / \mathrm{dl})$ & $138 \pm 38$ & $\mathrm{NS}$ & $127 \pm 44$ & $\mathrm{NS}$ & $147 \pm 75$ & $\mathrm{NS}$ & $171 \pm 89$ \\
Cholesterol $(\mathrm{mg} / \mathrm{dl})$ & $191 \pm 26$ & $\mathrm{NS}$ & $188 \pm 32$ & $\mathrm{NS}$ & $194 \pm 37$ & $\mathrm{NS}$ & $202 \pm 46$ \\
HDL-C $(\mathrm{mg} / \mathrm{dl})$ & $37 \pm 11$ & 0.001 & $49 \pm 8$ & 0.001 & $54 \pm 10$ & $\mathrm{NS}$ & $52 \pm 13$ \\
LDL-C $(\mathrm{mg} / \mathrm{dl})$ & $115 \pm 2$ & 0.001 & $98 \pm 32$ & 0.05 & $105 \pm 38$ & $\mathrm{NS}$ & $119 \pm 59$ \\
Apo A-l $(\mathrm{mg} / \mathrm{dl})$ & $129 \pm 23$ & 0.001 & $165 \pm 24$ & 0.001 & $140 \pm 17$ & 0.001 & $105 \pm 12$ \\
Apo B $(\mathrm{mg} / \mathrm{dl})$ & $80 \pm 14$ & 0.001 & $58 \pm 19$ & 0.001 & $72 \pm 12$ & 0.001 & $81 \pm 23$ \\
\hline
\end{tabular}

Group I : Obese children, Group II : children control, Group III : Hereditarily predisposed to coronary heart disease, Group IV: Parent with premature myocardial infarction.

NS = not significant ; $p<0.05$ : low-significant, $p<0.01$; significant, $p<0.001$ : very significant statistical differences. 


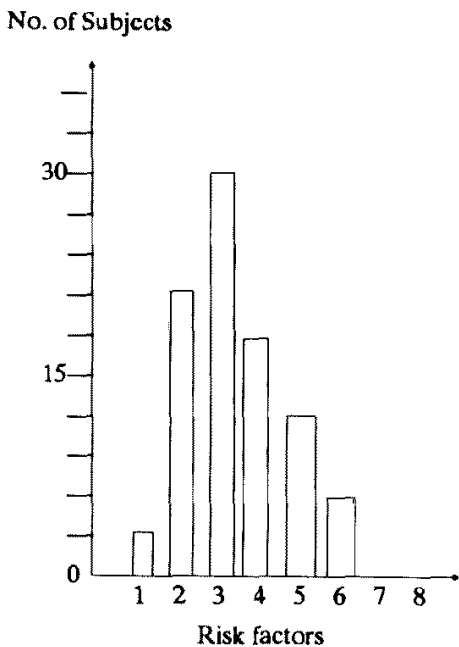

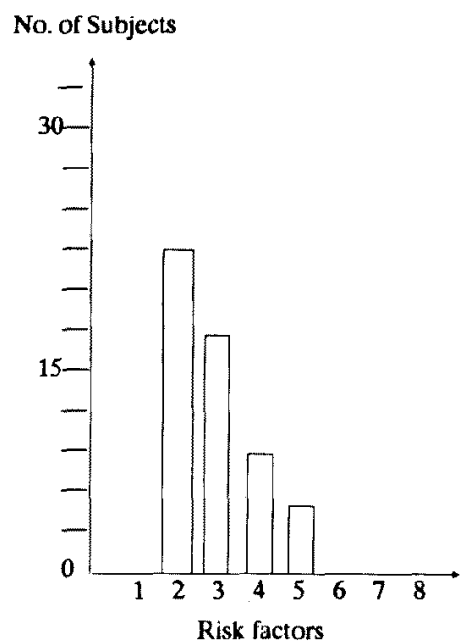

is

Fig. 1. Coronary artery disease risk factors in the obese (A) and having familial history of PCHD (B) children.

\section{Discussion}

Obese adolescents have an alarmingly high incidence of multiple coronary heart disease risk factors. ${ }^{10)-13}$ ) In the Wilmore, ${ }^{10)}$ Lauer, ${ }^{11}$ Gilliam et $\mathrm{al}^{14}{ }^{14}$ and Frip et al ${ }^{12}$ ' studies, approximately $14,4.6,36$, and $11 \%$ of the adolescents were reported to possess two or more coronary heart disease risk factors, with obesity the most prominent. In the Becque et al study, 35/36 obese adolescents had four or more risk factors. ${ }^{8)}$

In our study, $75 \%$ of obese children had three or more risk factors for CHD and $24 \%$ of them showed hypertension. Although plasma triglycerides and total cholesterol values did not differ from those of the controls, the obese children had lower HDL-C and Apo A-1 values and higher LDL-C and Apo $B$ values than controls $(\mathrm{p}<0.001)$. Becque et $\mathrm{al}^{8)}$ indicated that changes in blood pressure and other coronary heart disease risk variables may be achieved with diet and exercise intervention. The American Heart Association stated that exercise is an important factor leading to a more efficient cardiovascular system and reducing atherosclerotic risk. ${ }^{15}$ )

Patients with Type II, III, and IV familial hyperlipoproteinemias have a high risk for CHD. ${ }^{16)}$ Aortic stcnosis and CHD are complications of familial Type II hyperlipoproteinemia in early decades. In 2 cases presented by Özme et al, ${ }^{17)}$ familial hypercholesterolemic xanthomatosis was detected as a homozygous phenotype of familial Type II hyperlipoproteinemia. In 
both patients, supravalvular aortic stenosis, dermal fibroxanthomas, coronary atherosclerotic occlusions with high levels of cholesterol and lipoproteins were diagnostic for the disease.

Individuals with a family history of PCHD are at increased risk of developing CHD. ${ }^{18)}$ Among myocardial survivors under 60 years of age, with premature CHD about $15 \%$ have familial hyperlipoproteinemia, and a much smaller percentage, about $5 \%$, have heterozygous familial hypercholesterolemia. ${ }^{19)}$ About one-third of the children of parents suffering from myocardial infarction before the age of 50 years were found to have primary dyslipoproteinemia. ${ }^{18}$ ) Özme et al ${ }^{20)}$ investigated the plasma cholesterol and triglyceride levels of children from families where one parent had a myocardial infarction before age 45 . The average cholesterol and triglyceride values were significantly higher than control levels and half of their patient population had a prebeta band in the lipoprotein electrophoresis, compared with $8.1 \%$ in the control group. ${ }^{201}$

The findings in our study confirm previous reports in the literature. Perova et $\mathrm{al}^{91}$ reported that a paternal coronary heart disease group had lower levels of HDL-C and Apo A-1, higher levels of LDL-C, triglycerides and apoprotein $B$ than a control group, with blood pressure lability. In the Sveger et $a^{21)}$ study, $14 \%$ of the 84 children with family histories of premature CHD had abnormally high T-Cholesterol and LDL-C concentrations and $13 \%$ of parents had abnormal T-Cholesterol and LDL-C concentrations. In $6 \%$ of the high risk families abnormal tests were found in both children and parents. Atilgan et $\mathrm{al}^{22)}$ also reported that T-Cholesterol and LDL-C concentrations were significantly elevated in children whose parents had premature CHD. In our study, $60 \%$ of children with a family history of premature CHD had three or more risk factors for CHD. Triglycerides were higher than $200 \mathrm{mg} / \mathrm{dl}$ in $11 \%$ of both fathers and children. Apo A-1 levels were lower $(\mathrm{p}<0.001)$ and LDL-C and Apo B levels were higher $(\mathrm{p}<$ $0.05, p<0.001$, respectively) than controls in this population. These findings, then, suggest that obese children and children with a family history of premature CHD may have a greater risk of atherosclerosis. Measures such as diet and exercise must be considered for prevention.

\section{REFERENCES}

1. Enos WF, Holmes RH, Beyer JG: Coronary disease among United States soldiers killed in action in Korea. JAMA 152: 1090, 1953

2. McNamara JS, Malot MA, Stremple JF, et al: Coronary artery disease in combat casualties in Viet Nam. JAMA 216: 1185, 1971

3. Jacobson MS, Lillienfeld DE, Engin MS: The pediatrician's role in atherosclerosis preven- 
tion. J Pediatr 112: 836, 1988

4. Srinivason SR, Freedman DS, Sharma G, Webber LS, Berenson GS: Serum apolipoproteins $\mathrm{A}-1$ and $\mathrm{B}$ in 2,854 children from a biracial community. Bogaluse Heart Study. Pediatrics 78: 189,1986

5. Cardiovascular profiles of 15,000 children of school age in three communities, 1971-1975. National Heart, Lung, and Blood Institute, DHEW publication, Washington DC, US Dep. of Health and Human Services, p 1472, 1978

6. Stary HC: Macrophages, macrophage foam cells, and eccentric internal thickening in the coronary arteries of young children. Atherosclerosis 64: 91, 1987

7. Miller NE, Hammet F, Rao S: Relationship of angiographically defined coronary artery disease to plasma lipoprotein subfractions and apolipoproteins. Br Med J 282: 1741, 1981

8. Becque MD, Katch VL, Rocchimi AP, Marks CR, Moorehead C: Coronary risk incidence of obese adolescents: Reduction by exercise plus diet intervention. Pediatrics 81: 605, 1988

9. Perova N, Aingorn H, Metelskaya V, Dorofecva T, Belekonj N: Plasma lipid and apolipoprotein levels in children hereditarily predisposed to coronary heart disease. Acta Paediatr Scand 77: 559, 1988

10. Wilmore JH, McNamara JJ: Prevalance of coronary heart disease risk factors in boys 8 to 12 years of age. J Pediatr 84: 527, 1974

11. Lauer RM, Gonnor WE, Leaverton PE, et al: Coronary heart disease risk factors in school children: The Muscatine study. J Pediatr 86: 697, 1975

12. Frip RR, Hodgson JL, Kwitcrovich PO, et al: Aerobic capacity, obesity, and atherosclerotic risk factors in male adolescents. Pediatrics 75: 813, 1985

13. Blumenthal $\mathrm{S}$, Jesse MJ, Hennekens $\mathrm{CH}$, et al: Risk factors for coronary artery disease in children of affected families. I Pediatr 87: 1187, 1975

14. Gilliam TB, Katch VI, Thorlan V, et al: Prevalence of coronary heart disease risk factors in active children 7 to 12 years of age. Med Sci Sports Exerc 9: 21, 1977

15. Riopel DA, Boerth RG, Coates TJ, et al: Coronary risk factor modification in children: Exercise. Circulation 74: 1189A, 1986

16. Fredrickson DS, Levy RI: Familial hyperlipoproteinemia. in Metabolic Basis of Inherited Disease, ed by Stanbury JB, Wyngaarden JB, Fredrickson DS, McGraw-Hill, New York, p 565, 1972

17. Özme S, Sarikayalar F: Familial hiperkolesterolemik ksantomatozis. Çocuk Sagligi ve Hastaliklari Dergisi 20: 89, 1977

18. Glueck CJ, Gallat RW, Tsang RC, Buncher CR: Hyperlipidemia in progeny of parents with myocardial infarction before age 50. Am J Dis Child 127: 70, 1974

19. Goldstein JL, Schortt HG, Hazzord WR, et al: Hyperlipidemia in coronary heart disease. II. Genetic analysis of lipid levels in 176 families and delineation of a new inherited disorder, combined hyperlipidemia. J Clin Invest 52: 1544, 1973

20. Ozme S, Ege M, Ozalp I, Ciliv G: Serum lipids and lipoproteins in children from families with early coronary heart disease. The Turkish Journal of Pediatrics 19: 67, 1977

21. Sveger T, Fex G, Borgfors N: Hyperlipidemia in school children with family histories of premature coronary heart disease. Acta Paediatr Scand 76: 311,1987

22. Atilgan N, Eker R, Cantez T: Serum lipids and cholesterol levels in children whose parents had premature heart disease. Türkiye Klinikleri Kardiyoloji 2: 120, 1989 